\title{
Payment of Tax Dues and Workers' Wages in Bankruptcy in Indonesia
}

\author{
Rahayu Hartini \\ University of Muhammadiyah Malang, Indonesia \\ rahayuhartini@yahoo.co.id, hartini@umm.ac.id
}

\begin{abstract}
This Bankruptcy Research focuses on: how the payment between tax debt and wages of workers which by law both are entitled to take precedence. In practice there is debatable-fighting over each other, resulting in legal uncertainty. Until then there is a Judicial Review to the Constitutional Court in 2013. This legal research is Normative juridical by using the statute and conceptual approach. The data already obtained are analyzed by content analysis. The results of the study indicate that based on Decision of the Constitutional Court No.67/PUU-XI/2013, in the event of bankruptcy, the right of prior to the tax debt is not valid when it meets with the wages of workers and other workers' rights. The Constitutional Court's decision puts wages of workers as the first priority and then the state's right of tax debt. This is somewhat different from the separatist Creditor where if there is a payment of wages the separatist creditor succumbs but not to the payment of the rights of other workers.
\end{abstract}

Keywords: bankruptcy, payment, tax debt, wage worker, judicial review

\section{INTRODUCTION}

Bankruptcy is a common confiscation of all the wealth of bankrupt debtors whose management and ordering is done by the Curator under the supervision of the Supervisory Judge. The conditions to be declared bankrupt in principle is very simple (Article 2 paragraph (1) UUK and PKPU, namely: 1) Debtor who has two or more creditors, 2) .No payment for at least one debt has fallen and can be collected, 3). At his sole request or at the request of one or more of his creditors.

In practice, a lot of unequal judges' understanding of the Commercial Court is found in this regard. Another problem related to the implementation of separatist rights when it is attributed to tax collecting and collecting rights, there is often a legal uncertainty in its application so that what is earlier to be paid between the tax debt and the wage of workers becomes unclear. This happens because of the two provisions of the Conflicting Laws namely the Tax Law and the Law on Manpower [1].

Some previous research that has been done by the author related to bankruptcy issues, among others, is about; Authority of Commercial Court in Settlement of Bankruptcy Entitlement of Pacta Sunt Servanda In
Resolving Bankruptcy Dispute [4], Legal Protection Against the Defaulted Airlines [5], Legal Status Of Bank Guarantee On Behalf Of Third Parties In Bankruptcy Perspective.

While another research has been done by other researchers: Insolvency Indicators as Conditions of Bankruptcy Under Indonesian Bankruptcy Law [6] Bankruptcy of Joint Operation And The Responsibilities The Member of Joint Operation [7], Cross-border bankruptcy in the Perspective of International Law And Comparison With National Instruments In Some Countries [8], The Right of Preceding Debt Collection for Taxpayers which are Declared as Bankrupt (Manurung, n.d.), The Authority of the Public Prosecutor as Applicant Bankrupt For State Interest on Tax Debt The Subject of Law Of ASEAN Non-Indonesian Country After the Entry into Force of AEC [9].

The difference of this research with some previous author's research with other authors is that in this study is more focus to review bankruptcy when it is associated with the existence of creditors consisting of taxes and workers. The legal issues are: How is the payment between tax debt and wages of workers or laborers in bankruptcy after them Decision of the Constitutional Court Year 2013? So, in this case, it must be known the position between tax debts with wage laborers as creditor in bankruptcy so that it will be known the sequence in its payment when happened bankrupt.

\section{METHOD}

This type of research is a normative juridical research, because the matter which is studied is the philosophy of the norms related to the principal issues studied, namely norms in the field of Bankruptcy Law, Labor Law and Tax Law, especially related to the tax debt also concerns the aspect of justice and legal certainty. By using the approach of the law statute and conceptual [10]. By using primary and secondary legal materials, which are primary: legislation in the field of Bankruptcy and PKPU, Labor Law and Taxation Code (KUP). Secondary, obtained from textbooks/literatures, journals of law and the results of previous studies that discussed related to the issue of law in this study. The analysis is done by content analysis by comparing with the doctrine, theory and principle of law presented by 
experts, based on reasoning or logic in legal argumentation. Analysis is done to find the truth.

\section{RESULTS}

\section{Payments of Taxes and Wages of Workers in Bankruptcy}

\section{a. Position of Tax Debt in Bankruptcy}

The position of tax debt is different from other debts. Tax liability arises from the Act and does not arise as a result of legal relations among citizens. Tax liability can be imposed because it involves the obligation of citizens to the state. However, the wider understanding of citizens is that including all foreign individuals who live in the territory of Indonesia for more than 183 days and earn income from business entrenched in Indonesia (see Article 2 Ayat (4) Law No 7 Year 1983 and Law No. 36 Year 2008 .

The position of tax debt in the Civil Code has placed the tax debt to take precedence over other creditors as regulated in Articles 1134 and 1137 Civil Code. Based on Article 1134 and 1137 Civil Code, the position of tax debt as a holder of privileges with preceding right refers to the regulation in special law, namely the Law of KUP.

Judging from the broad sense of debt in UUK-PKPU, debt is a liability that can arise from agreements or from contracts that are born under the law. Debts or tax bills must be settled by the taxpayer or the taxpayer. Taxpayers in exercising their rights and obligations in accordance with the tax laws and regulations may be represented among others by the Board. Bodies that have been declared bankrupt then the curator is tasked to make arrangements and order debtor bankruptcy property. The state has a prior right to the tax debt on all debtor's possessions. The preceding rights are stipulated in Article 21 paragraph (1) of the KUP Law, which reads: "The state has the preceding right to tax debt on the goods of the Taxpayer".

The preceding right in Article 21 Paragraph (1) of this KUP Law also stipulates that the state as the preferred creditor is deemed to have prior rights over the property of the taxpayer to be auctioned publicly. Payments to other creditors are settled after the tax debt is paid. Provisions on prior rights include tax principal, administrative sanctions in the form of interest, penalties, increases, and tax collection fees [2].

The provisions of Article 21 of the KUP Law are in line with Article 1137 Civil Code which regulates the State Rights as follows: "The right of the state treasury, auction office and other public bodies established by the government, to take precedence, orderly exercise of such rights, and that right, regulated in various special laws regarding it ".

The special law regulating the matters referred to in Article 1137 of the Civil Code is one of the special KUP Law of Article 21. Therefore, by referring to the above provisions on the right of the state to the payment of tax debt shall be placed as the holder of the right of the first position, followed by the separatist creditor (holders of mortgages, mortgage, fiduciary, mortgages).

\section{b. Position of Labor Wages in Bankruptcy}

The definition of wages as set forth in the Elucidation of Article 39 of UUK-PKPU is the right of workers received and expressed in the form of money in return of the employer to the worker for a work or service which has been or will be done, determined and paid according to an employment agreement, or legislation, including benefits for workers and families. Since the date of decision of the bankruptcy statement is pronounced, the wages owed before and after the declaration of bankruptcy declaration is pronounced is a debt of bankruptcy.

The provision is contained in Article 39 paragraph (2) UUK-PKPU. A bankrupt company may not be able to pay its creditors so that it can also have wage debt to the employee.

In the Manpower Act also regulates the preceding

right of Article 95 Paragraph (4) and its Elucidation has regulated the position of debt of wages of employees or employees of bankrupt debtors as follows:

"In the case of a company declared bankrupt or liquidated under applicable laws and regulations, and other rights of the worker / laborer shall be the debt of the payment ". Under this provision, the position of the worker shall be the creditor, then in the event of bankruptcy, the labor rights shall be equal to the other creditors. The problem is the position of the worker as the creditor in which classification (separatist, preferred, or concurrent creditors) as this will determine the order of priority of payment.

Article 1134 of the Civil Code describes the following privileges: "Privilege is a right granted by law to a creditor that causes him to be higher than the other, solely on the nature of the receivable. Pawn and hypothec are higher than privileges, unless the law expressly defines the reverse".

Regarding Privileges is further stipulated in Article

1149 of the Civil Code: "The privilege of all movable and immovable objects in general: a) ........, b). Worker's salary over the past year and wages paid in the current year, along with the money to be paid by the employer either to the workers or to the workers' families".

Article 95 Paragraph (4) of the KT Law shall place the wage of workers in the position of the Preferential Lender, as it has the privilege granted by the Act. From the provisions of Article 1134 of the Civil Code, it is explained that the creditors of mortgage lenders and mortgages have a higher level than the privileged creditor, unless the law expressly regulates otherwise. Thus, if the KT Law wishes to exclude that privilege position is higher than a mortgage and mortgage (Separatist Creditor), the KT Law must state specifically that its rate is higher than Separate Creditors are not contained in the Law on KT. This resulted in the wage of his/her employee under his Separatist Creditor. The provision of Article 95 Paragraph (4) of the Law on Right and Regulatory Body does require companies that have bankruptcy to comply with the fulfillment of workers' rights such as severance pay and other rights. As a result, in practice, the notion of the word 
"precedence of payment" is placed after the repayment of the rights of the state and its separatist creditors. This problem is often the cause of debate in case of bankruptcy. [11]

c. Decision of Constitutional Court No. 67 / PUU-XI / 2013 [12]

Based on the decision of the Constitutional Court, it is clear that if there is bankruptcy, the right to precede the tax debt is not valid if it meets the wages of workers / workers and other workers' rights. This is somewhat different from separatist creditors if there is a wage payment for workers / laborers then the separatist creditor succumbs but not to the payment of the rights of other workers.

The consideration of the Panel of Judges to decide this is the wage of workers/laborers constitutionally based on Article 28 D Paragraph (2) of the 1945 Constitution is a constitutional right which is therefore also a constitutional right to obtain fair and decent treatment in the employment relationship.

As for the obligations / bills of the state, it is reasonable to be ranked after wages and workers' rights (such as severance pay, gratuity and compensation pay and so forth).

This is because countries have other sources of financing whereas for workers, wages are the only source of survival for themselves and their families. So with the decision of the Constitutional Court which places the wages of workers as the first priority of payment in the event of bankruptcy, the next priority is the state's right namely tax debt.

\section{CONCLUSION}

Based on Decision of the Constitutional Court No.67/ PUU-XI/2013, that in the event of a bankruptcy, the right to precede the tax debt is not valid when it meets with the wages of workers and other workers' rights. The MK's ruling places the wages of workers as the first priority of payment in the event of bankruptcy, and further the state's right of tax debt. This is somewhat different from the separatist Creditor where if there is a payment of the wages of the worker / laborer then the separatist creditor succumbs but not to the payment of the rights of other workers.

\section{REFERENCES}

[1] Hartini, R. Legal Status of Bank Guarantee on Behalf of Third Parties in. Yustisia, 6, Nomor 1(1),
190-198. https://jurnal.uns.ac.id/yustisia, 2017

[2] Fernandez. Tinjauan yuridis hak mendahulu pelunasan utang pajak atas harta pailit dan penyelesaian utang pajak dalam kepailitan skripsi. Universitas Indonesia. Retrieved from http://lib.ui.ac.id/file?file=digital/20289052S1197- Fernandez.pdf, 2012

[3] Hartini, R. Model Penyelesaian Kasus Kepailitan Dengan Klausul Arbitrase (Sebuah Resolusi Konflik Dualisme Hukum Kepailitan Dan Arbitrase di Indonesia). Jurnal Ilmu Hukum Amanna Gappa, 16, Nomor, 1-25, 2008

[4] Hartini, R. Hukum Kepailitan Indonesia Ditinjau Dari Aspek Epistemologi dan Aksiologi. Yustika, Media Hukum Dan Keadilan, FH Ubaya, 12, No.2, 131-236, 2009

[5] Hartini, R. UUK dan PKPU No 37 Tahun 2004

[6] Mengesampingkan Berlakunya Asas Pacta Sunt Servanda Dalam Penyelesaian Sengketa Kepailitan. Yustisia, 4, Nomor 2(37), 292-309. Retrieved from https://jurnal.uns.ac.id/yustisia, 2015.

[7] Hidayah, L. N. (2016). Jurnal Ilmu Hukum, Volume 6, Nomor 2, Oktober, 2015. Jurnal Ilmu Hukum, 7, Nomor 1, 134-144. https://repository.unja.ac.id/613/1/8. Lili Naili.pdf.

[8] Hartini, R. Legal Status of Bank Guarantee on Behalf of Third Parties in. Yustisia, 6, Nomor 1(1), 190-198. Retrieved from https://jurnal.uns.ac.id/ Yustisia , 2017.

[9] Hardjaloka, L. Kepailitan Lintas Batas Perspektif Hukum Internasional Dan Perbandingannya Dengan Instrumen Nasional Di Beberapa Negara. Yuridika, 30(3), 385. https://doi.org/10.20473/ydk.v30i3.1952, 2015.

[10] Arjaya, B. G. M. W. Wewenang Kejaksaan Sebagai Pemohon Pailit Untuk Kepentingan Negara Terhadap Utang Pajak Subyek Hukum Dari Negara ASEAN Non Indonesia Pasca Berlakunya AEC. Jurnal Rechts Vinding, Media Pembinaan Hukum Nasional, 3, Nomor 2(10), 197-213, 2014.

[11] Marzuki, P. M. Penelitian Hukum (Revisi). Jakarta: Kencana_Prenada Media, 2009.

[12] Fauzi, $\bar{W}$. Arrangement of Investment-Based Insurance after the Enactment of Law No 40 Year 2014 on Insurance. Journal of Law, Policy and Globalization, 65(40), 128-133. Retrieved from www.iiste.org, 2017.

[13] Putusan Mahkamah Konstitusi Republik Indonesia Nomer: 67/PUU-XI/2013. 